\title{
'Disegno dal vero e dell'immaginario': le verità di un ossimoro visivo
}

\author{
Anna Marotta \\ Rossana Netti \\ Ornella Bucolo \\ Nadia Fabris \\ Daniela Miron \\ Claudio Rabino
}

\section{Abstract}

Pare che in alcuni Corsi di Laurea in Architettura le "magnifiche sorti e progressive" della tecnologia digitale sempre più avanzata abbiano generato la quasi totale scomparsa del disegno manuale e tradizionale. II dominio dell'immagine digitale, che si impone come nuova forma di comunicazione visiva, regala l'illusione che si possa prescindere dalle forme di rappresentazione tradizionali, tanto da pensare di poterle escludere dal percorso formativo dell'architetto. Restando fermi nella convinzione che sia, invece, indispensabile per un architetto avere una solida cultura del Disegno, da quello tradizionale alle modalità più innovative, un contributo prezioso viene fornito dal Workshop di Disegno dal Vero e dell'Immaginario, inserito nei Corsi di Laurea Magistrale in Architettura, presso il Politecnico di Torino. II nome scelto per questo corso racchiude in sé un evidente ossimoro, nell'ottica di conciliare due aspetti apparentemente contraddittori, ma in realtà complementari. In un'epoca in cui la comune visione tridimensionale dell'opera d'arte può essere integrata o sostituita da una realtà virtuale, alcuni termini come 'fantastico', 'immaginario' o 'visionario', assumono una diversa funzione. Così, paradossalmente (in architettura e non solo), la rappresentazione della realtà 'virtuale' viene impiegata per meglio rappresentare il 'vero' e la realtà. II presente contributo affronterà in prevalenza il secondo approccio proposto nel corso e cioè quello dell'immaginario.

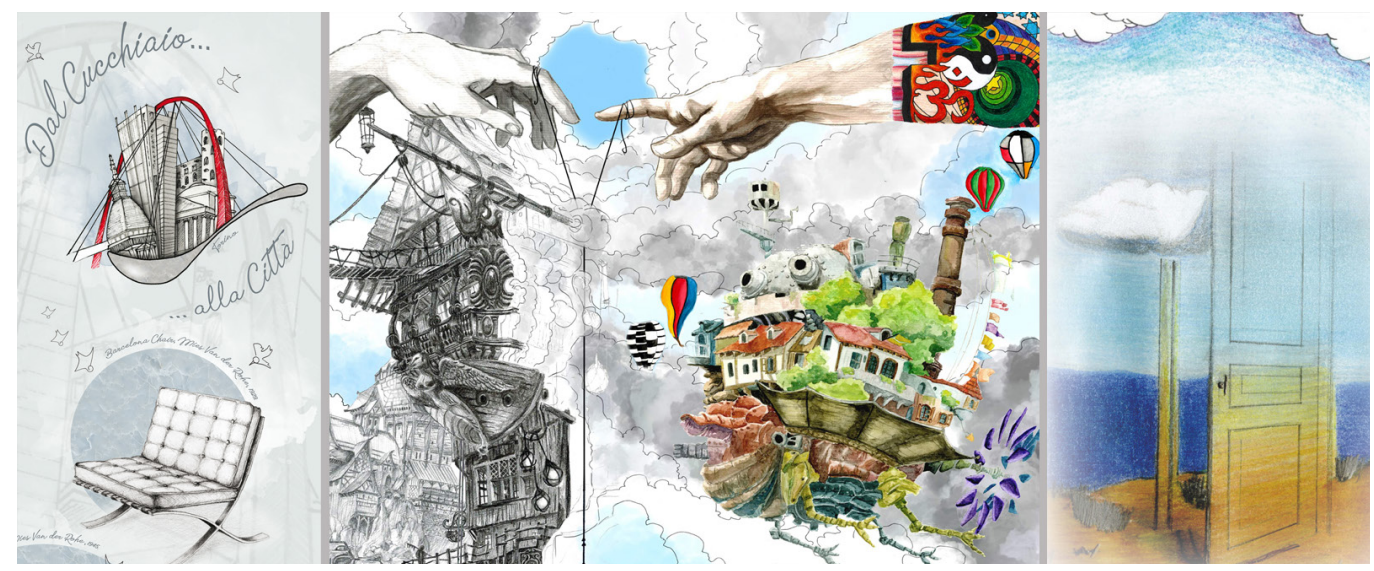




\section{Connessioni e ricuciture nel Disegno}

Saper disegnare è come saper suonare uno strumento musicale o praticare uno sport: consente di acquisire una disciplina e nello stesso tempo migliora la conoscenza di sé e il proprio modo di esprimersi. II disegno, compreso quello di architettura, è un potente ed efficace collante che fa incontrare e unisce gli allievi/architetti ai loro docenti. Oltre a questa, quante altre connessioni sono possibili? Quali tipi di connessioni e ricuciture sono leggibili con il disegno e nel disegno?

Nel corso di Disegno dal Vero e dell'Immaginario, si è sempre partiti da alcuni interrogativi da sottoporre agli studenti: "Quale significato senti di dare alla 'tua' architettura, alla 'tua' città, alla 'tua' vita di architetto? Pensi che l'architettura sia solo un fatto tecnico e concreto o che possa esprimere anche altri contenuti, di fantasia, di immaginazione, o valori tuoi personali, che porti dentro e vuoi condividere?" Lo studente viene dunque stimolato prima di tutto a 'connettersi con sé stesso', con le proprie matrici culturali, con la realtà da rappresentare e/o modificare tramite il progetto, infine con il proprio immaginario.

Un altro fondamentale passo riguarda le modalità per comunicare attraverso la visione. II 'racconto visivo' può diventare uno specchio, che riflette la nostra cultura, la nostra anima; quindi l'immaginario si conferma come percorso (anche disciplinare) del proprio io e nel proprio io.

Stiamo attraversando un momento storico in cui la riflessione sulla cultura visiva, ma anche la più diffusa pratica dell'atto del vedere, torna ad essere molto attuale, avvalorata da un sempre più ampio utilizzo - in certi casi non adeguatamente consapevole e critico - delle immagini nella pratica scientifica.

\section{Tra 'verita' e 'immaginazione'}

Come ricorda Alberto Castoldi, Baudelaire, interrogandosi sullimmaginazione, ne forniva una definizione geniale: "L'immaginazione scompone tutta la creazione e, con i materiali raccolti e disposti secondo regole di cui non si può trovare l'origine se non nel più profondo dell'anima, crea un mondo nuovo, produce la sensazione del nuovo" [Castoldi 20 I2].

Nel tempo, dell'immaginario sono state proposte definizioni di vario tipo, tutte comprese in una 'facoltà immaginativa' di difficile individuazione. Jean-Jacques Wunenburger ne ha tracciato la storia nella sua Philosophie des images (1997). L'accezione, maturata nel corso del Novecento, si conferma nella sua radice francese, poi diffusa anche in quella italiana, molto meno nella cultura inglese. A Sartre si deve invece una riflessione specifica su questa problematica nel suo saggio sull'Imaginaire (1940): "Il metodo è semplice: produrre in noi delle
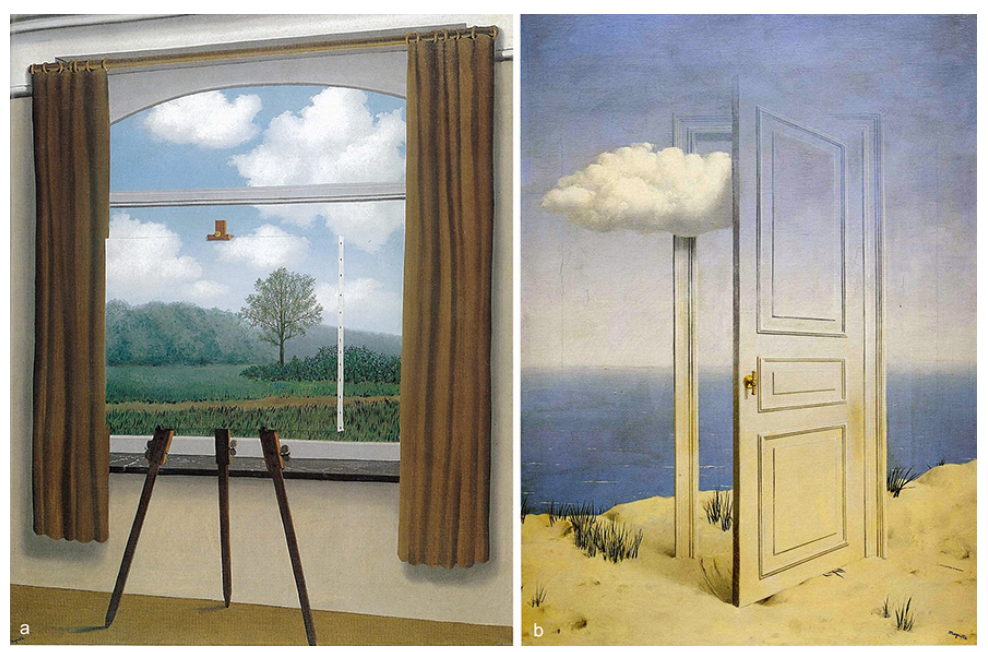
immagini, riflettere su queste immagini, descriverle, vale a dire tentare di stabilire e classificare le loro caratteristiche distintive" [Sartre 2007, p. 20 I]. Per Sartre, l'atto immaginativo è un incantesimo destinato a far apparire l'oggetto a cui si pensa, la cosa che si desidera, in modo che se ne possa prendere possesso; diverse le posizioni di Gaston Bachelard e di Gilbert Durand. Pur avendo in comune la radice junghiana, Bachelard in particolare distingue fra le due polarità: una maschile (Animus) e una femminile (Anima). II suo primo obiettivo è quello di distinguere i caratteri della Scienza dalle contaminazioni dell'immaginazione, per cui è la ragione che deve eliminare gli spazi da lei assegnati al sogno, perché la fantasia svolge un ruolo di ancella rispetto alla cognizione. Nella sua 'psicanalisi del fuoco' egli sostiene: "se la materia onirica si condensa un po' nell'anima del sognatore la rêverie si trasforma e precipita nel Rêve" [Bachelard 20 I0, p. 17]. Nella Poetica dello spazio scrive inoltre che, per chiarire filosoficamente il problema dell'immagine poetica, si deve ricorrere ad una fenomenologia dell'immaginazione "Intendiamo con questo uno studio del fenomeno dell'immagine poetica quando l'immagine emerge nella coscienza come un prodotto diretto del cuore, dell'anima, dell'essere, dell'uomo colto nella sua attualità" [Bachelard 2006, p. 16]. Questo concetto sembra essere dimostrato dagli studi di Piaget, secondo cui le rappresentazioni soggettive si esplicano "attraverso gli accomodamenti anteriori del soggetto all'ambiente soggettivo" [Piaget, Inhelder 1977, p. 219]. Meno netti e articolati appaiono i successivi contributi di Wunenburger, che assegna all'immaginario il compito di dare forma e di costituirsi come modalità di rappresentazione.

In conclusione possiamo dire che l'immaginario non concerne direttamente il reale, poiché le narrazioni letterarie e visive (intese anche come modelli mentali) servono a interpretare, ricostruire e rappresentare detta realtà nelle forme più disparate: i miti e i riti ne sono parte rilevante, come modalità espressiva, anche se non esclusiva. E lo stesso vale per la realtà umana: l'immaginario è un modo di connessione anche da parte dell'Uomo. Mediante vari modi narrativi (segnici, pittorici, musicali) si può prendere coscienza di sé e comunicare con altri, proprio grazie al potere totalizzante di un 'racconto' che dà forma all'informe.

Dunque, come sostiene Castoldi, l'immaginario - attraverso le sue declinazioni - consente di "tessere una tela condivisa" che serve da strumento comunicativo per la collettività; questa tela va rielaborata continuamente a seconda delle problematiche che di volta in volta si vanno imponendo. Ci troviamo dunque a confrontarci con una sorta di dizionario mentale dell'immaginario che nella sua elaborazione coniuga logica e sensibilità, come affermava Mallarmé [Castoldi 20I2].

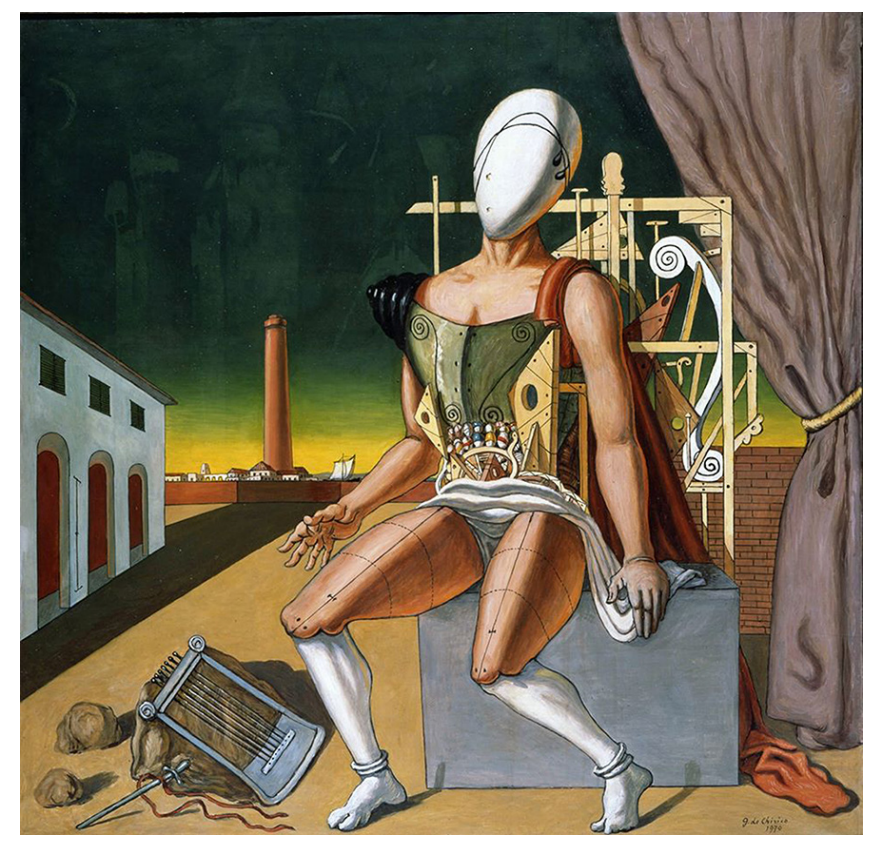


Fig. 3. Fabrizio Clerici, Un istante dopo, 1978. Una suggestiva scenografia evocatrice di archeologie fantastiche, un miraggio sospeso nel viaggio della
Fra i movimenti artistici che più si riconoscono nella stessa dimensione, possiamo qui ricordare alcune esperienze: dal Surrealismo di Magritte (fig. I a e Ib), alla Neometafisica (di marca futurista) di De Chirico (fig. 2), fino alle susseguenti espressioni, dagli anni '60 in poi, dell'Iperrealismo in America, del Nouveau Rèalisme in Francia e di nuove forme di realismo in Italia: magico, ideologico, psicologico, esistenziale, visionario, con Fabrizio Clerici (fig. 3) ed Enrico Baj, fino ad arrivare al Transrealismo di Guadagnuolo (fig. 4a e 4b). A questi modelli, più o meno programmaticamente, appaiono ispirate le scelte degli studenti del corso.

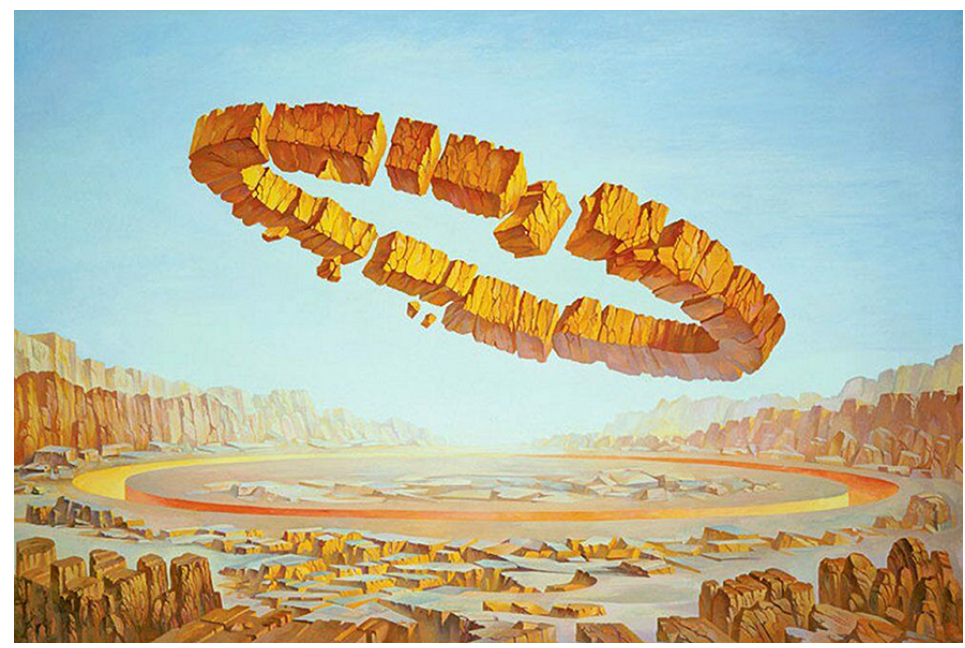

\section{Disegnare: forma, geometria, colore, traccia, segno, simbolo}

II Disegno resta il linguaggio fondativo e un eccezionale 'modo narrativo' per l'architetto: egli pensa, progetta e comunica principalmente per via visiva e grafica.

Ma l'attività del 'Disegnare' non può mai essere separata dall'azione del 'Vedere', alla quale occorre 'educarsi' in maniera altrettanto razionale, colta e critica, per compiere nel modo più efficace possibile scelte quali, ad esempio, quella fondamentale del punto di vista. Completato in questo senso, il Disegno, in tutte le sue forme, componenti ed espressioni, si conferma come linguaggio formale irrinunciabile [Netti 2019]. Quindi, anche la traccia grafica, dalla tecnica alla creatività, all'arte, può essere confermata come segno teso a mostrare, ma anche a comunicare, un significato [Marotta 20l0].

Segno e immagine, tecnica ed espressione, procedimento individuale e risultato figurativo personale, sono momenti differenti di un medesimo fenomeno che, nel nostro caso, è il disegno dell'architetto, il suo pensiero primo.

Attraverso singole prove e applicazioni mirate e testate, relative anche al modo di usare il 'mezzo tracciante', si costruisce un piccolo bagaglio di esperienze necessario per un progetto grafico efficace e coerente con gli obiettivi del corso. Altrettanto decisivo si rivela il ruolo del colore, in tutte le sue forme e i suoi approcci, dalle teorie al progetto cromatico, alla prassi, anche con l'uso di tecniche ad acquerello [Marotta 1999; Rabino 2017].

E stato anche dimostrato che per progettare e realizzare un efficace 'racconto visivo' è indispensabile documentarsi, studiare, riflettere e altro ancora: una prassi indispensabile per la Comunicazione Visiva, nell'analisi e nel progetto [Hachen 2007].

Nell'universo della rappresentazione grafica, intesa come esito della cultura della visione, il segno come traccia grafica è uno dei più potenti, significativi ed espressivi elementi di linguaggio, dagli aspetti più diretti, materici e naturali (velocità, pressione, emozionalità nel tracciamento) a quelli più culturali e artistici, affidati agli aspetti metaforici ed evocativi. II contributo considera dunque (secondo la Nouvelle Réthorique, da Hjelmslev a Greimas) 
il segno come traccia grafica nelle sue componenti di 'significante' (piano dell'espressione) e 'significato' (piano del contenuto) in esempi come: la pittura cinese, la Gestalt (psicologia della forma), la grafica liberty, le psicografie futuriste (per esempio Marinetti e Benedetta), l'espressionismo astratto americano, da Robert Motherwell e Mark Rothko al dripping di Jackson Pollock, fino a Hans Hartung, senza dimenticare l'esperienza fondativa di Keith Haring [Kanizsa 1980; Arnheim 1984; Kepes 1986; Pirenne 1991; Marotta 20I I].

In conclusione, l'aspetto formativo-professionalizzante fondamentale sta nella possibilità, che solo il Disegno consente, di proiettare e di mostrare l'idea formale e spaziale del progetto, in tutti i modi possibili: dal più semplice, basico ed elementare a quello più complesso e dettagliato, declinabile peraltro in tutte le sue accezioni (materiali, funzionali, immaginarie, simboliche e così via). E insieme a ciò, garantirne il controllo, negli esiti formali e tecnici.

Così vissuta, l'educazione (l'educarsi) al 'Disegnare' diventa un'avventura che non finirà mai, per tutta la vita, professionale e non, senza discontinuità, ricostruendo connessioni, di tutti i tipi.

Fig. 4. Francesco Guadagnuolo: a) Gli perspazi e l'energia del segno - Gll iperspazi e la fica (formule, equazion e grafici autografi di Giuseppe Arcidiacono) 1995, collage e tecnica mista $70 \times 50 \mathrm{~cm}$; b) Transrealismo: la nuovo realtà visionaria, 2012
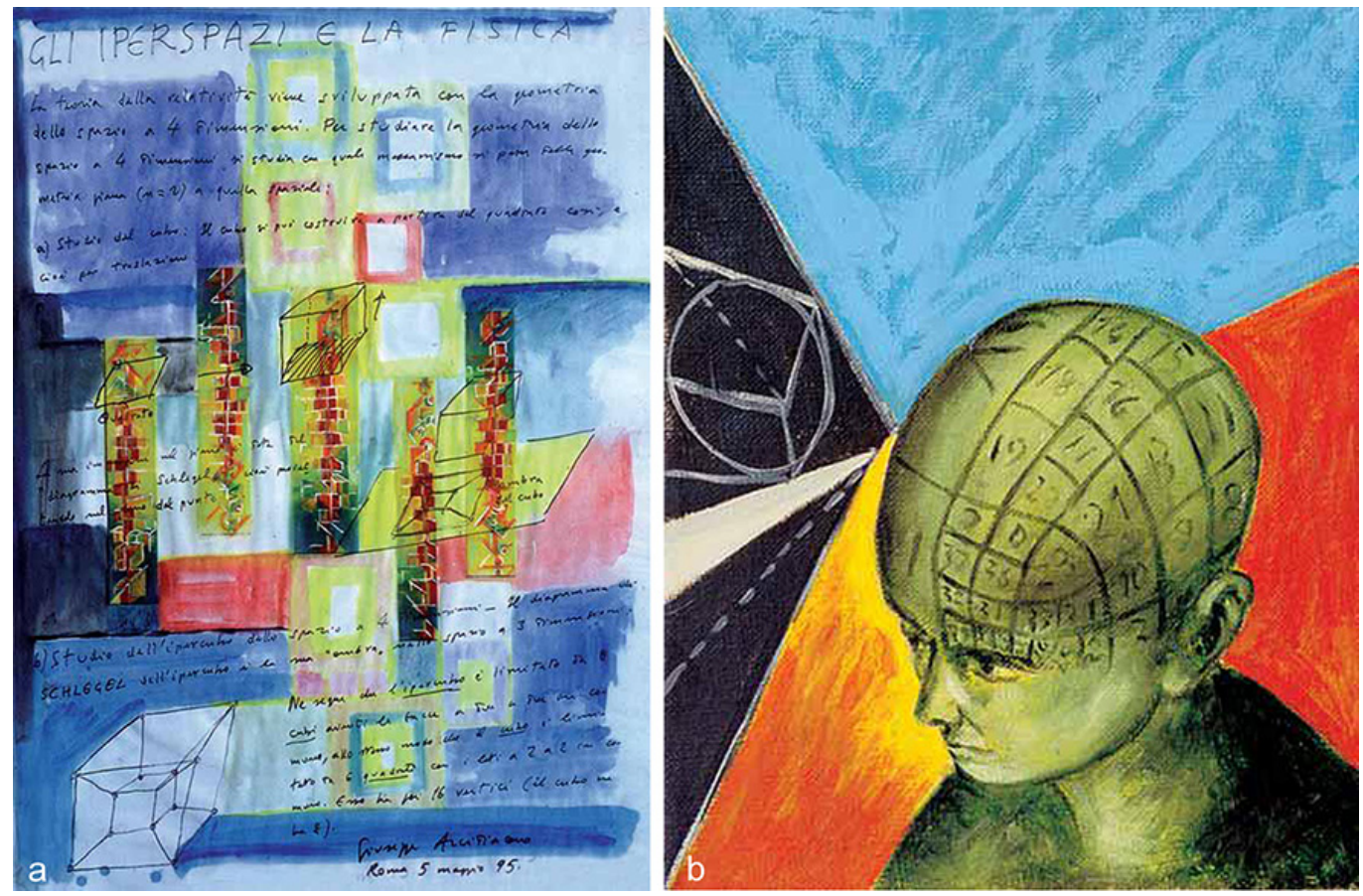

\section{Gli esiti: letture, interpretazioni e risposte degli studenti}

Le varie esperienze proposte agli studenti durante il corso hanno consentito loro di mettere in atto un complesso processo di trasformazione del mondo esterno (e non solo): "arrivare in un luogo, osservarlo, percepirlo, analizzarlo e infine rappresentarlo" [Albissini, Chiavoni, De Carlo 20 I 0, p. 33] con il filtro delle personali emozioni, della propria memoria e della propria cultura.

Gli esiti di questo processo sono stati molteplici, variegati, ambiziosi, con diverse sfumature dettate dal proprio essere e dal proprio vissuto.

Le tavole prodotte sono dei veri e propri racconti di vita, espressi attraverso l'Architettura, il Paesaggio, la Natura, il Colore, la Moda, l'Immaginario...

Grazia racconta (fig. 5): "I primi due disegni sono tratti dal catalogo della mostra "Ruskin, le pietre di Venezia"; ciò che mi ha affascinata è l'attenzione al dettaglio d'architettura nelle cattedrali gotiche, come se in essi fosse racchiusa l'essenza più vera e profonda dell'intero 
Fig. 5. Grazia Pognani, Natura in Architettura, 2018. II rapporto tra architettura e natura è stato approfondito e declinato nel caso studio specifico dell'ornamento e della decorazione.

Fig. 6. Martina Di Gloria, Dal bianco e nero al colore 2018. manufatto. È l'architettura che si ispira alla natura e la natura che diventa architettura. Nelle vetrate liberty possiamo cogliere lo spirito dei primi anni del Novecento. Uno sguardo rivolto al futuro, con l'esaltazione del progresso tecnologico e lo sviluppo industriale, e uno al passato nel trarre ispirazione ancora una volta dalla natura, un tema trasversale nella storia dell'Uomo, che travalica il passare del tempo e le differenze culturali".

Giacomo afferma (fig. 7): "Questo disegno è una metafora dei miei difetti, delle mie qualità e del modo in cui mi vedo in questo momento. Come molti dei miei disegni, anche questo è caratterizzato da un'ambiguità grafica di fondo, con i vari elementi che si mischiano e confondono fra di loro per trovare legami impossibili nella realtà ma fattibili nei sogni e nell'immaginazione. È una scenografia che rappresenta la passione per le arti. È anche un cantiere, ad indicare non solo l'amore per l'architettura ma anche un senso di incompletezza. II mio presente e il mio futuro sono ancora in costruzione".

Alice spiega il suo percorso immaginario (fig. 9): "La lettura della tavola deve partire dal basso, dove è collocato un disegno dello skyline di Torino: la quotidianità da cui voglio scappare.
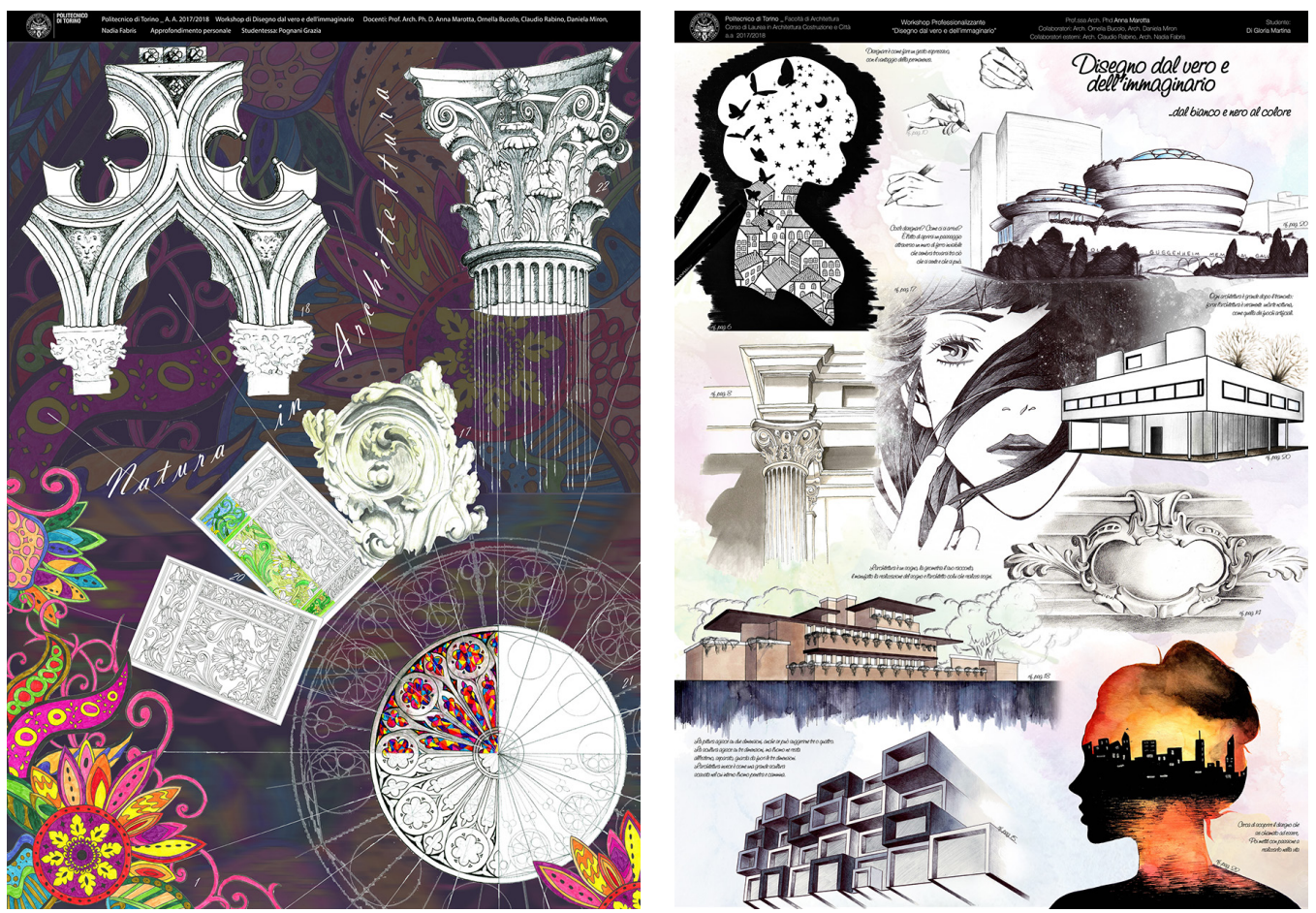

Idealmente la mia persona è simboleggiata da una farfalla che vola attraverso i vari scenari e si fa più piccola a mano a mano che il viaggio prosegue, per poi volare via per la sua strada e sparire... Dopo vari scenari Alice torna a Torino, precisamente nel disegno che rappresenta Villa della Regina, a lungo abbandonata, per poi essere restaurata. lo mi paragono a questa villa, poiché dopo il mio viaggio onirico introspettivo, tra l'architettura e i giardini, anche in me qualcosa è cambiato. Torno alla mia realtà "restaurata" con una nuova consapevolezza, dopo aver avuto la possibilità di riflettere, guardare nel mio mondo interiore e scegliere la mia strada. In questo manifesto c'è molto di me, della mia persona e di quelle che sono le mie emozioni".

Fabio elabora una riflessione (fig. 10): "La parte del disegno a colori ha il compito di rappresentare tutte le sensazioni ed emozioni che l'uomo moderno non ha più il tempo di assaporare a causa dei ritmi frenetici della vita e dell'alienazione che la tecnologia comporta. II mio obiettivo è quello di mostrare il cambiamento del mondo percepito dal punto di vista 
Fig. 7. Giacomo Pregnolato, Il disegno immaginario, 2018.

Fig. 8. Cynthia Andorno Okafor, Fashion Wearing Architecture, 2018."'La moda è come l'architettura, è solo una questione di proporzioni" (Coco Chanel). di una persona che "vede" intorno a sé ciò che la circonda, accorgendosi così dei dettagli e riempiendosi gli occhi di colore. II rapporto tra un soggetto che "vede" e uno che non ha nemmeno il tempo di "guardare" è la dimensione principale della mia rappresentazione. La parte di tavola in bianco e nero raffigura un mondo distopico dove la tecnologia ha preso il sopravvento sull'essere umano e lo ha svuotato della sua essenza, rendendolo un automa. Gli uomini che camminano allineati, richiamano il simbolo per eccellenza dell'arte non conformista che però ha perso ogni sua caratteristica e si è adeguata al contesto. L'architettura anch'essa ha perso i suoi connotati: semplice, lineare e funzionale non ha bisogno di decorazioni per mostrarsi ad un pubblico che tanto non avrebbe tempo e volontà di fermarsi ad ammirarla".

Sara così esplicita il suo racconto visivo (fig. 12): "Secondo la mia interpretazione, il colore azzurro può essere inteso tramite un duplice significato: azzurro come il colore degli stati d'animo e azzurro come il colore dei sogni. Come ormai tutti sanno i colori influenzano l'umore e molti credono che i colori a cui siamo esposti per un lungo periodo, abbiano
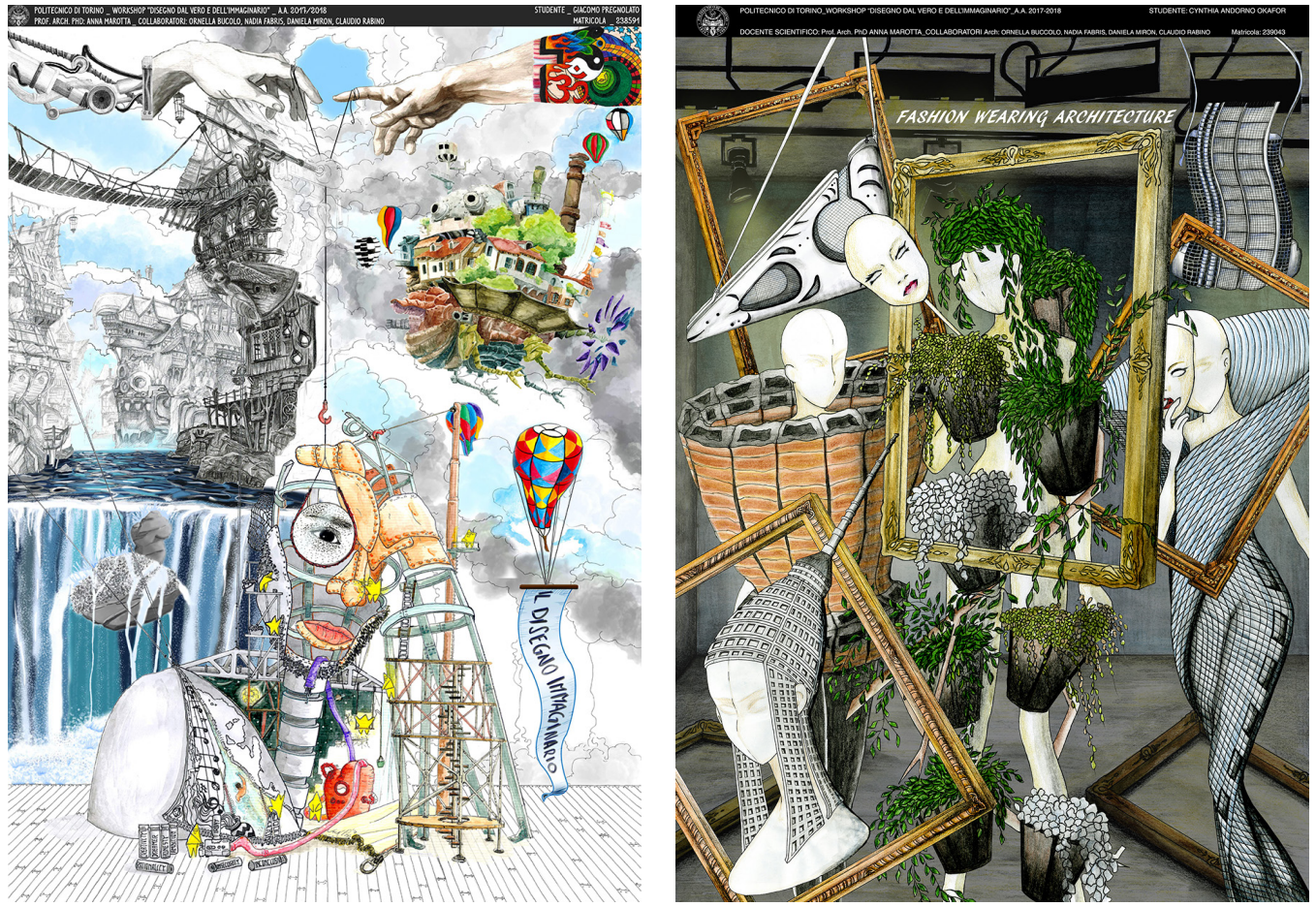

il potere di aiutare a curare le malattie. II colore azzurro, nei suoi toni più chiari, riporta ad immagini di infanzia, delicatezza e innocenza; dà sensazioni di pulizia, freschezza, purezza, giovinezza. Lo stesso colore è accostato alla serenità emotiva e all'armonia, da cui discendono sentimenti di tranquillità e positività. Nei sogni i colori sono l'espressione delle emozioni e degli stati d'animo da cui siamo sopraffatti momentaneamente o per lunghi periodi".

Gli esempi qui riportati (da fig. 5 a fig. 12) dimostrano come il piano dell'espressione (il mezzo) dipenda fortemente da quello del contenuto (il messaggio): dai contenuti a dai linguaggi formali, fino alle scelte tecniche e di realizzazione, nulla in questo processo è mai neutrale o casuale, ma è invece influenzato dal vissuto, dalla cultura, dallo stato d'animo e da mille altri fattori. Dunque una grande presa di coscienza da parte degli studenti.

Un esempio illuminante è da riconoscersi nella porta di Magritte (La Victoire) (fig. Ib), che in modo surreale 'apre' la narrazione visiva che abbiamo inteso proporre e in modo altrettanto immaginario e simbolico 'chiude' la stessa narrazione, con l'esperienza di Sara (fig. I2). 
Fig. 9. Alice Targa, Alice nel giardino delle meraviglie, 2019. II manifesto rappresenta la 'fuga dalla realtà' attraverso un viaggio 'onirico' tra i giardini e l'architettura, in Cu l'autrice si rifugia.

Fig. I0. Fabio Gazzola, II mondo in bianco e nero e non, 2019 .

Fig. I . Barbara Marcovecchio, Dal Cucchiaio allo Città, 2019. È la celebre espressione coniata d Ernesto Rogers nel 1952 nella Carta di Atene, volendo spiegare l'approccio tipico di un architetto che dalla progettazione un cucchiaio, di una sedia di una lampada, si trova a dover lavorare su un grattacielo.

Fig. 12. Sara Celoria, Realtà in azzurro, 2019. manifesto vuole rappresentare differenti realtà reali e non, il cui color dominante è l'azzurro.



\section{Riferimenti bibliografici}

Albissini Piero, Chiavoni Emanuela, De Carlo Laura (a cura di). (20l0). Verso un disegno "integrato". La tradizione del disegno nell'immagine digitale. Roma: Gangemi Editore.

Arnheim Rudolph (1984). Arte e percezione visiva. Milano: Feltrinelli.

Bachelard Gaston (2006). La poetica dello spazio. (Traduzione di E. Catalano). Bari: Dedalo.

Bachelard Gaston (20 I0). L'intuizione dellistante-La psicoanalisi del fuoco. (Traduzione di M. Bianchi). Bari: Dedalo.

Castoldi Alberto, 2012. In carenza di senso. Logiche dell'immaginario. Milano: Mondadori.

Hachen Massimo (2007). Scienza della visione: spazio e Gestalt, design e comunicazione. Milano: Apogeo.

Kanizsa Gaetano (1980). Grammatica del vedere: saggi su percezione e Gestalt. Bologna: II mulino.

Kepes Gyorgy (1986). Il linguaggio della visione. Bari: Dedalo.

Marotta Anna (1999). Policroma: dalle teorie comparate al progetto del colore. Torino: Celid.

Marotta Anna (20I0). Segno e simbolo, rilievo e analisi. L'esempio nell'ornatus architettonico. In Centofanti Mario, Brusaporci Stefano. Sistemi informativi integrati per la tutela la conservazione e la valorizzazione del patrimonio architettonico e urbano. Roma: Gangemi Editore, p. I12-121.

Marotta Anna (20I I). Retorica della visione: dal paesaggio urbano ai sememi. In: Gambardella Carmine (a cura di). Le vie dei mercanti, S.A.V.E. Heritage safeguard of architectural, visual, environmental Heritage. Capri, 9- I I giugno 20 I I, p. I- I 0. Napoli: La scuola di Pitagora.

Netti Rossana (2019). II disegno dell'antico come metafora di conoscenza, comunicazione e conservazione della memoria. In: Belardi Paolo (a cura di). Riflessioni | Reflections | L'arte del disegno/ll disegno dell'arte. Atti del $41^{\circ}$ Convegno dei Docenti delle Discipline della Rappresentazione. Perugia 19-2I settembre 20 19. Roma: Gangemi Editore, 20 I9, pp. 847-854.

Piaget Jean, Inhelder Bärbel (1977). La genesi delle strutture logiche elementari. Classificazione e seriazione. Firenze: La Nuova Italia.

Pirenne Maurice ( 199 |). Percezione visiva: ottica, pittura, fotografia. Padova: Muzio.

Rabino Claudio (2017).Trent'anni di arte e passione insieme. Torino: Politecnico di Torino, Regione Piemonte.

Sartre Jean-Paul (2007). L'immaginario. Psicologia fenomenologica dell'immaginazione (nuova edizione a cura di Raoul Kirchmayr). Torino: Einaudi.

Wunenburger Jean-Jacques (1997). Philosophie des images. Parigi: Presses Universitaires de France.

\section{Autori}

Anna Marotta, Politecnico di Torino, nannarella.marotta@gmail.com

Rossana Netti, Politecnico di Torino, rossana.netti@polito.it

Ornella Bucolo, Politecnico di Torino, ornella.bucolo@polito.it

Nadia Fabris, Politecnico di Torino, nadia.fabris@polito.it

Daniela Miron, Politecnico di Torino, daniela.miron@polito.it

Claudio Rabino, Politecnico di Torino, claudio.rabino@polito.it

Per citare questo capitolo: Marotta Anna, Netti Rossana, Bucolo Ornella, Fabris Nadia, Miron Daniela, Rabino Claudio (2020). 'Disegno dal vero e dell'immaginario': le verità di un ossimoro visivo/'Drawing from life and imagination': the truths of a visual oxymoron. In Arena A., Arena M., Bran-
dolino R.G., Colistra D., Ginex G., Mediati D., Nucifora S., Raffa P. (a cura di). Connettere. Un disegno per annodare e tessere. Atti del $42^{\circ}$ Convegno dolino R.G., Colistra D., Ginex G., Mediati D., Nucifora S., Raffa P. (a cura di). Connettere. Un disegno per annodare e tessere. Atti del $42^{\circ}$ Convegno
Internazionale dei Docenti delle Discipline della Rappresentazione/Connecting. Drawing for weaving relationships. Proceedings of the 42 th International Conference of Representation Disciplines Teachers. Milano: FrancoAngeli, pp. 608-625. 


\title{
'Drawing from Life and Imagination': the Truths of a Visual Oxymoron
}

\author{
Anna Marotta \\ Rossana Netti \\ Ornella Bucolo \\ Nadia Fabris \\ Daniela Miron \\ Claudio Rabino
}

Abstract

It seems that in some Degree Courses in Architecture the "magnifiche sorti e progressive" of increasingly advanced digital technology have generated the almost total disappearance of manual and traditional drawing. The dominion of the digital image, which imposes itself as a new form of visual communication, gives the illusion that one can disregard traditional forms of representation, so much so that one thinks one can exclude them from the architect's educational path. Staying firm in the belief that it is, instead, indispensable for an architect to have a solid culture of Drawing, from the traditional one to the most innovative modalities, the Drawing from Life and Imagination Workshop, included in the Master's Degree Courses in Architecture, at the Polytechnic of Turin, provides a valuable contribution in this sense. The name chosen for this course contains an obvious oxymoron, in order to reconcile two apparently contradictory but actually complementary aspects. In an age when the common three-dimensional vision of the work of art can be integrated or replaced by virtual reality, some terms such as 'fantastic', 'imaginary' or 'visionary' take on a different function. In this way, paradoxically (in architecture and not only), the representation of 'virtual' reality is used to better represent the 'real' and reality. The present contribution will deal mainly with the second approach proposed in the course, namely that of the imaginary.
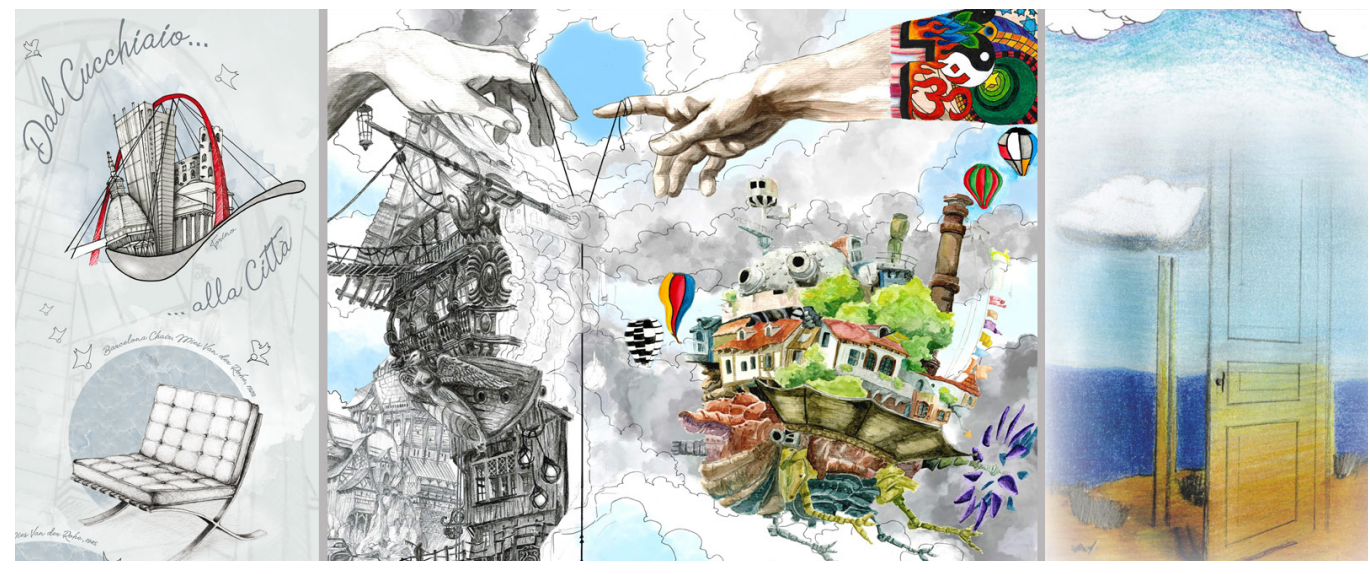


\section{Connections and restitching in the Drawing}

Know how to draw is how to play a musical instrument or practice a sport: it allows you to acquire a discipline, and at the same time improves self-knowledge and how to express yourself. Drawing, including architectural drawing, is a powerful and effective adhesive that brings together students/architects and their teachers. In addition to the one already mentioned, how many other connections are possible? What types of connections and mends are readable with the drawing and in the drawing?

In the course of Drawing from Life and Imagination, we have always started from some questions to ask the students: "What meaning do you feel you give to 'your' architecture, to 'your' city, to 'your' life of architect? Do you think that architecture is only a technical and concrete fact or that it can also express other contents, of fantasy, imagination, or your personal values, that you carry inside and want to share"? The student is therefore stimulated first of all to 'connect with himself', with his own cultural matrices, with the reality to be represented and/or modified through the project, and finally with his own imagination. Another fundamental step concerns how to communicate through vision. The 'visual storytelling' can become a mirror, reflecting our culture, our soul; therefore, the imaginary is confirmed as a path (also disciplinary) of our own self and in our own self.

We are going through a historical moment in which reflection on visual culture, but also the most widespread practice of the act of seeing, returns to be very current, supported by an ever wider use -in some cases not adequately aware and critical- of images in scientific practice.

\section{Between 'truth' and 'imagination'}

As Alberto Castoldi recalls, Baudelaire, asking himself questions about imagination, gave a brilliant definition:"Imagination breaks down all creation and, with the materials collected and arranged according to rules whose origin cannot be found except in the depths of the soul, creates a new world, produces the sensation of the new" [Castoldi 20I 2].

Over time, various definitions of the imaginary have been proposed, all included in an 'imaginative faculty' that is difficult to identify. Jean-Jacques Wunenburger traced its history in his Philosophie des images (1997). The meaning, matured during the twentieth century, is confirmed in the French root, is then spread in the Italian root, but much less in the English culture. Sartre, on the other hand, makes a specific reflection on this problem in his essay on Imaginaire (1940): "The method is simple: produce images in us, reflect on them, describe them, that is, try to establish and classify their distinctive characteristics"
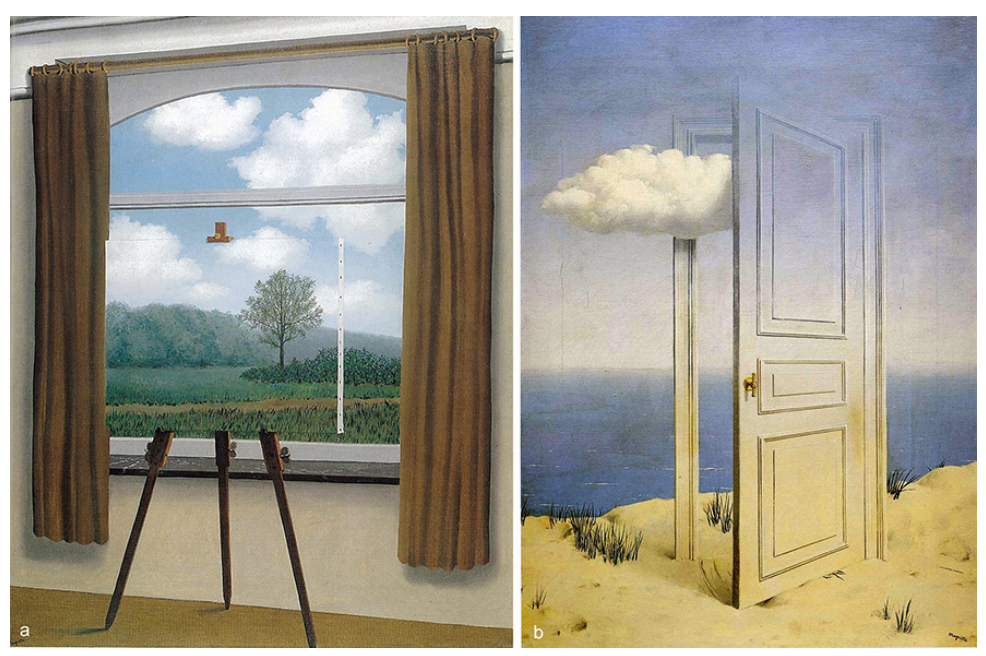
[Sartre 2007, p. 20 I]. For Sartre, the imaginative act is a spell designed to make the object you are thinking about appear, the thing you want, so that you can take possession of it; the positions of Gaston Bachelard and Gilbert Durand are different. While having the Jungian root in common, Bachelard in particular distinguishes between the two polarities: a male (Animus) and a female (Anima). Her first objective is to distinguish the characters of Science from the contaminations of imagination, so it is the reason why she has to eliminate the spaces she assigns to the dream, because imagination plays a handmaiden role with respect to cognition. In his 'psychoanalysis of fire' he argues: "if the oneiric matter condenses a little in the soul of the dreamer, the rêverie is transformed and falls into the Rêve" [Bachelard 20 I0, p. 17]. In the Poetics of space, he also writes that, in order to philosophically clarify the problem of the poetic image, one must resort to a phenomenology of the imagination "We intend with this a study of the phenomenon of the poetic image when the image emerges in the consciousness as a direct product of the heart, the soul, of being, of man caught in its actuality" [Bachelard 2006, p. I6]. This concept seems to be demonstrated by Piaget's studies, according to which subjective representations are made "through the subject's anterior accommodations to the subjective environment" [Piaget, Inhelder 1977, p. 219]. Less clear and articulated appear Wunenburger's subsequent contributions, which assigns to the imaginary the task of shaping and constituting itself as a mode of representation.

In conclusion we can say that the imaginary does not directly concern the real, since literary and visual narratives (also understood as mental models) serve to interpret, reconstruct and represent said reality in the most disparate forms: myths and rituals are a relevant part of it, as an expressive modality, even if not exclusive. And the same is true for human reality: the imaginary is a way of connection also on the part of Man. Through various narrative modes (sign, painting, music) one can become aware of oneself and communicate with others, thanks to the totalizing power of a 'story' that gives shape to the formless.

Therefore, as Castoldi maintains, the imaginary -through its declinations- allows us to "weave a shared canvas" that serves as a communicative tool for the community; this canvas must be continuously reworked according to the problems that are being imposed from time to time. We therefore find ourselves confronted with a sort of mental dictionary of the imaginary that in its elaboration combines logic and sensitivity, as Mallarmé said [Castoldi 20I2].

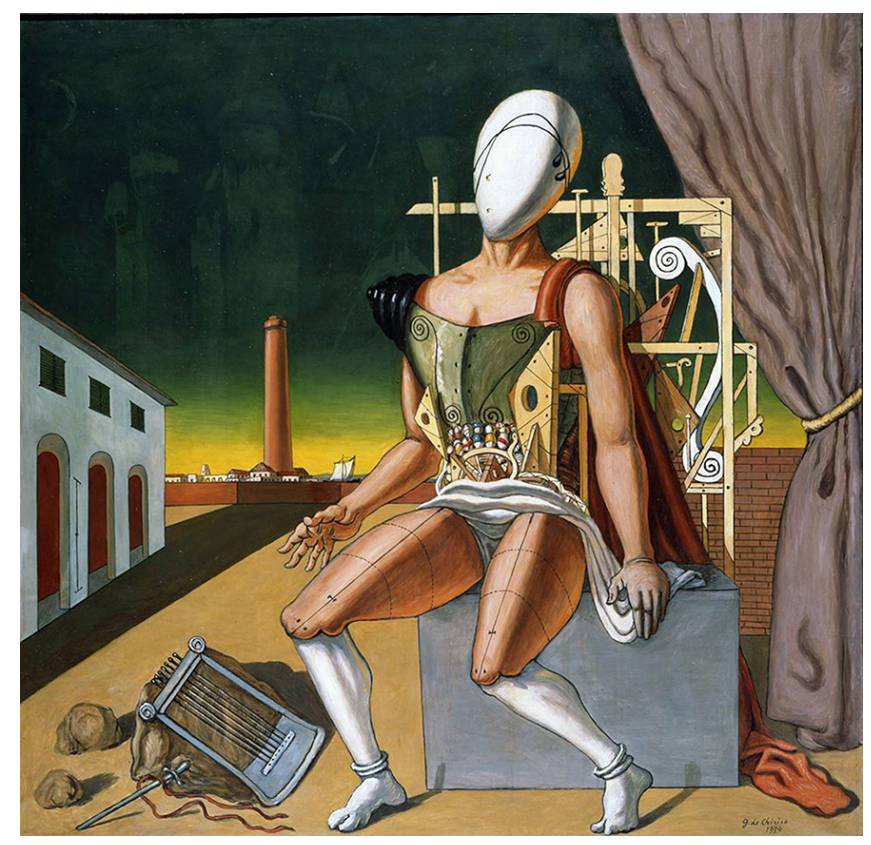


Among the artistic movements that are most recognizable in the same dimension, we can recall here some experiences: from Magritte's Surrealism (fig. I a, I b), to De Chirico's Neometaphysics (of futurist brand) (fig. 2), up to the subsequent expressions, from the 1960s onwards, of Hyperrealism in America, Nouveau Rèalisme in France and new forms of realism in Italy: magical, ideological, psychological, existential, visionary, with Fabrizio Clerici (fig. 3) and Enrico Baj, up to Guadagnuolo's Transrealism (fig. 4a, 4b). These models, more or less programmatically, seem to inspire the choices of the students of the course.

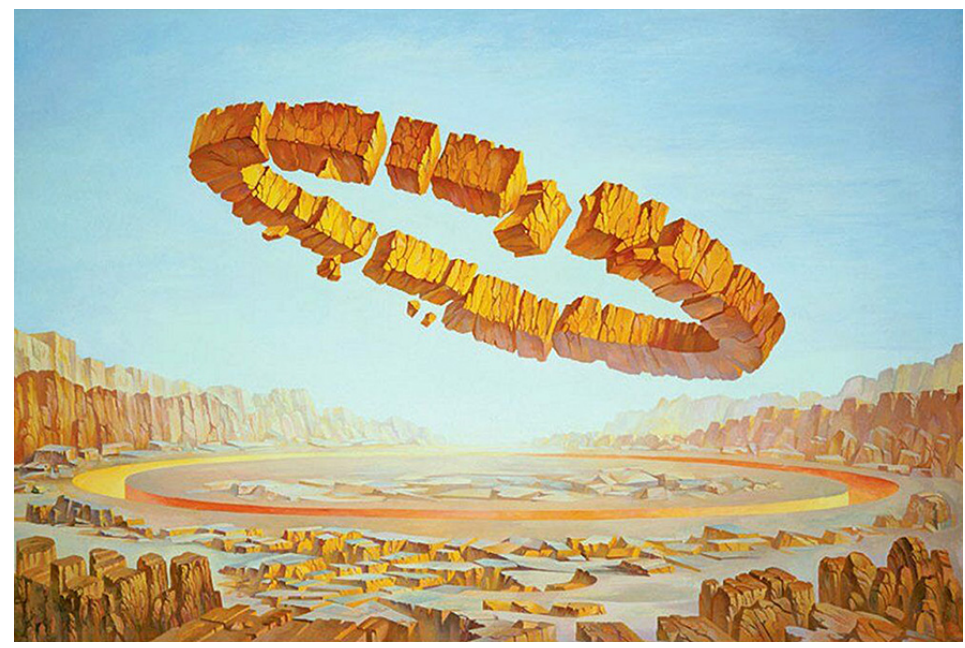

The Drawing: shape, geometry, colour, trace, sign, symbol

Drawing remains the founding language and an exceptional 'narrative mode' for the architect: he thinks, designs, communicates mainly by visual and graphic means.

But the activity of 'Drawing' can never be separated from the action of 'Seeing', to which it is necessary to 'educate' oneself in an equally rational, cultured and critical way, in order to make choices as effectively as possible, such as, for example, the fundamental one of the point of view. Completed in this sense, Drawing, in all its forms, components and expressions, is confirmed as an essential formal language [Netti 20l9]. Therefore, even the graphic trace, from technique to creativity, to art, can be confirmed as a sign aimed at showing, but also at communicating, a meaning [Marotta 20l0].

Sign and image, technique and expression, individual procedure and personal figurative result, are different moments of the same phenomenon which, in our case, is the architect's design, his first thought.

Through single targeted and tested tests and applications, also related to the way to use the 'tracer medium', a small amount of experience is built up which is necessary for an effective graphic design and consistent with the objectives of the course. Equally decisive is the role of colour, in all its forms and approaches, from theories to colour design, to practice, even with the use of watercolour techniques [Marotta 1999; Rabino 20 I7]. It has also been demonstrated that in order to design and implement an effective 'visual narrative' it is essential to document, study, reflect and more: an indispensable practice for Visual Communication, in analysis and design [Hachen 2007].

In the universe of graphic representation, understood as the outcome of the culture of vision, the sign as a graphic trace is one of the most powerful, significant and expressive elements of language, from the most direct, material and natural aspects (speed, pressure, emotionality in tracking) to the more cultural and artistic aspects entrusted to metaphorical and evocative aspects. The contribution therefore considers (according to the Nouvel- 
le Réthorique, from Hjelmslev to Greimas) the sign as a graphic trace in its components of 'signifier' (plane of expression) and 'meaning' (plane of content) in examples such as: Chinese painting, Gestalt (psychology of form), Art Nouveau graphics, Futurist psychographics (e.g. Marinetti and Benedetta), American abstract expressionism, from Robert Motherwell and Mark Rothko to Jackson Pollock's dripping, up to Hans Hartung, not forgetting Keith Haring's founding experience [Kanizsa 1980; Arnheim 1984; Kepes 1986; Pirenne 199I; Marotta 20II].

In conclusion, the fundamental formative-professionalizing aspect lies in the possibility, that only Drawing allows, to project and show the formal and spatial idea of the project, in every possible way: from the simplest, basic and elementary to the most complex and detailed, which can be declined in all its meanings (material, functional, imaginary, symbolic and so on). And together with this, to guarantee its control, in its formal and technical results. In this way, education (educating oneself) to 'Drawing' becomes an adventure that will never end, for all life, professional or not, without discontinuity, rebuilding connections of all kinds.
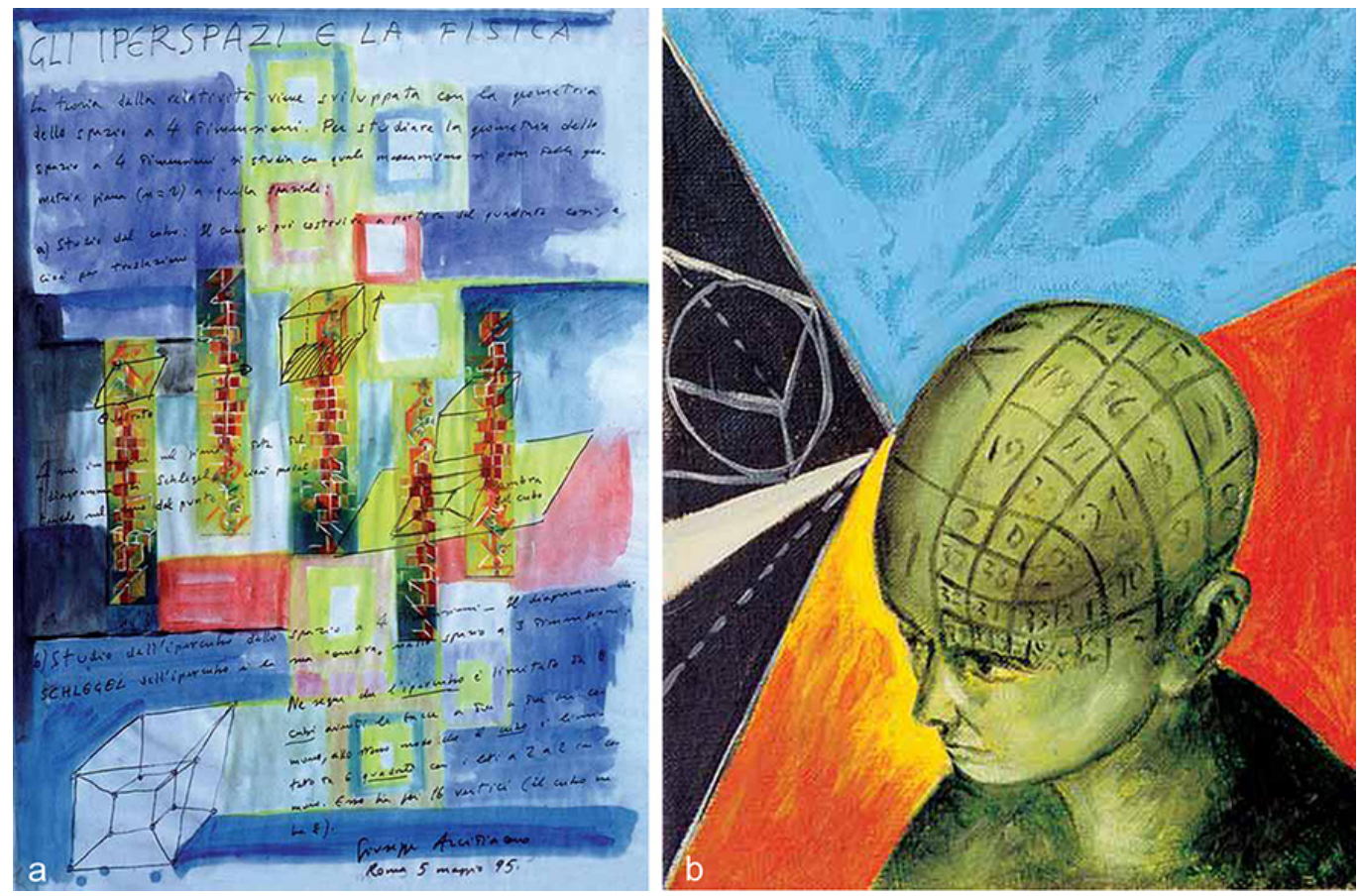

The outcomes: readings, interpretations and responses of students

The various experiences offered to students during the course allowed them to implement a complex process of transformation of the external world (and not only): "arrive in a place, observe it, perceive it, analyse it and finally represent it" [Albissini, Chiavoni, De Carlo 2010, p. 33] with the filter of own emotions, own memory and own culture.

The results of this process have been many, varied, ambitious, with different nuances dictated by one's own being and own just lived.

The tables produced are real stories of life, expressed through the Architecture, Landscape, Nature, Colour, Fashion, Imaginary...

Grazia tells (fig. 5):"The first two drawings are taken from the catalogue of the exhibition "Ruskin, the stones of Venice"; what fascinated me is the attention to detail of architectu- 

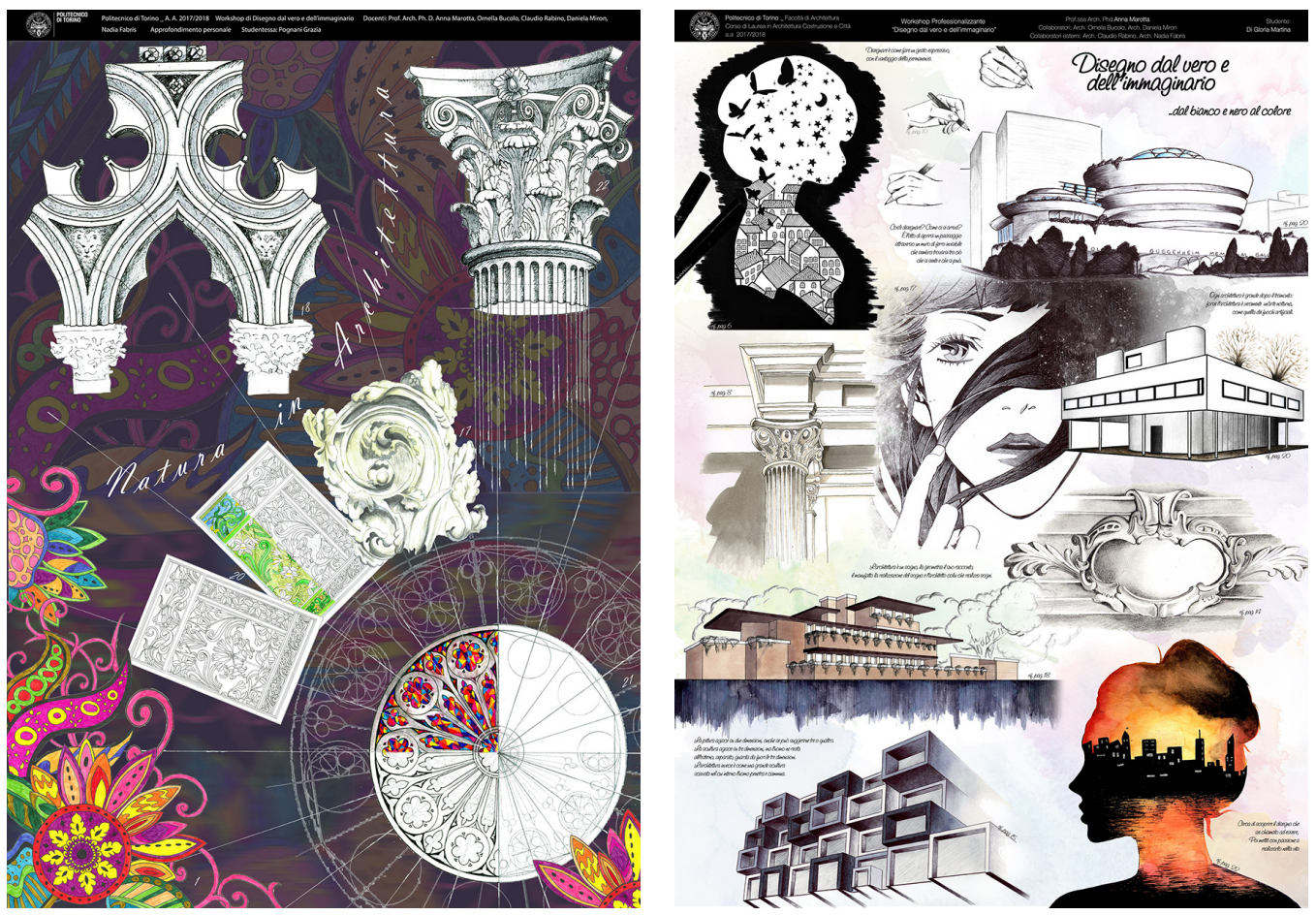

Alice explains her imaginary path (fig. 9): "The reading of the elaborate graphic must start from the bottom, where a drawing of the Turin skyline is placed: the everyday life from which I want to escape.

Ideally my person is symbolized by a butterfly that flies through the various scenarios and gets smaller as the journey continues, to then fly away on its way and disappear... After various scenarios Alice returns to Turin, precisely in the drawing that represents the Queen's Villa, long abandoned, and then restored. I compare myself to this villa, because after my oneiric introspective journey, between the architecture and gardens, something has changed in me too. I return to my 'restored' reality with a new awareness, after having had the opportunity to reflect, look into my inner world and choose my own way. In this manifesto there is a lot of me, of my person and of my emotions".

Fabio elaborates a reflection (fig. I0):"The colour drawing part has the task of representing all the sensations and emotions that modern man no longer has time to savour due 
Fig. 7. Giacomo Pregnolato, The imaginary drawing, 2018.

Fig. 8. Cynthia Andorno Okafor, Fashion Wearing Okat, Fashion Weaning shion is like architecture. shion is like architecture it's just a matter of proportion" (Coco Chanel) to the frenetic paces of life and the alienation that technology entails. My goal is to show the change of the world perceived from the point of view of a person who 'sees' around himself what surrounds him, so noticing the details and filling himself his eyes with colour. The relationship between a subject who 'sees' and one who doesn't even have time to 'look' is the main dimension of my representation. The black and white part of the elaborate graphic depicts a dystopian world where technology has taken over the human being and emptied him of his essence, making him an automaton. The men who walk in line, recall the symbol par excellence of non-conformist art that however has lost all its characteristics and has adapted to the context. Architecture, too, has lost its connotations: simple, linear and functional, it does not need decorations to show itself to an audience that in any case would have no time or willingness to stop and admire it".

Sara explains her visual story in this way (fig. I2): "According to my interpretation, the colour blue can be understood through a double meaning: azure as the colour of moods and blue as the colour of dreams. As everyone knows by now colours affect mood and
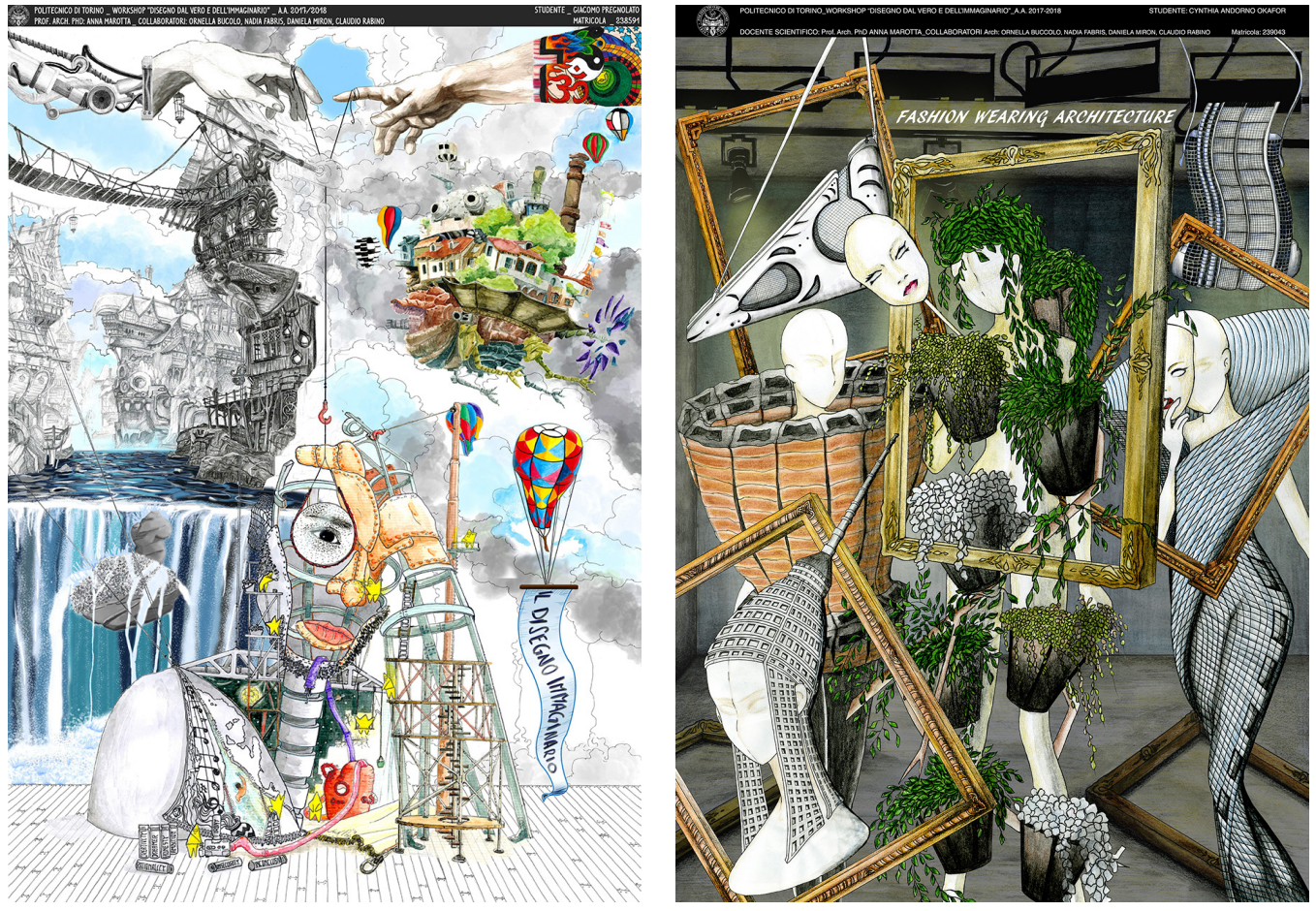

many believe that the colours we are exposed to for a long time have the power to help cure illnesses. The colour blue, in its lighter tones, brings back images of childhood, delicacy and innocence; it gives feelings of cleanliness, freshness, purity, youth. The same colour is associated to emotional serenity and harmony, from which descend feelings of tranquillity and positivity. In dreams, colours are the expression of emotions and moods from which we are overwhelmed momentarily or for long periods".

The examples given here (from fig. 5 to fig. 12) show how the level of expression (the medium) strongly depends on the level of content (the message): from content to formal languages, up to technical and realization choices, nothing in this process is ever neutral or random, but is instead influenced by experience, culture, mood and a thousand other factors. So a great awareness on the part of the students.

An illuminating example is Magritte's door (La Victoire) (fig. Ib), which in a surreal way 'opens' the visual narration we proposed and in an equally imaginary and symbolic way 'closes' the same narration, with Sara's experience (fig. I2). 
Fig. 9. Alice Targa, Alice in the Garden of Wonders, 2019. The poster represents the 'escape from re journey between garden and architecture, in which Fig. 10. Fabio Gazzola, The world in black and white and not, 2019.

Fig. I I. Barbara Marcovecchio, From the spoon to the town, 2019."From the spoon to the town" is the slogan created by Ernesto Rogers in 1952 in the Athens Charter. He explained the typical approach of a Milanese architect, designing

spoon, a chair, and a lamp and in the same day wor

king on a skyscraper.

Fig 12 Sara Celoria, Reality in blue, 2019. The poster wants to represent different real and not rea realities, whose dominant colour is blue.
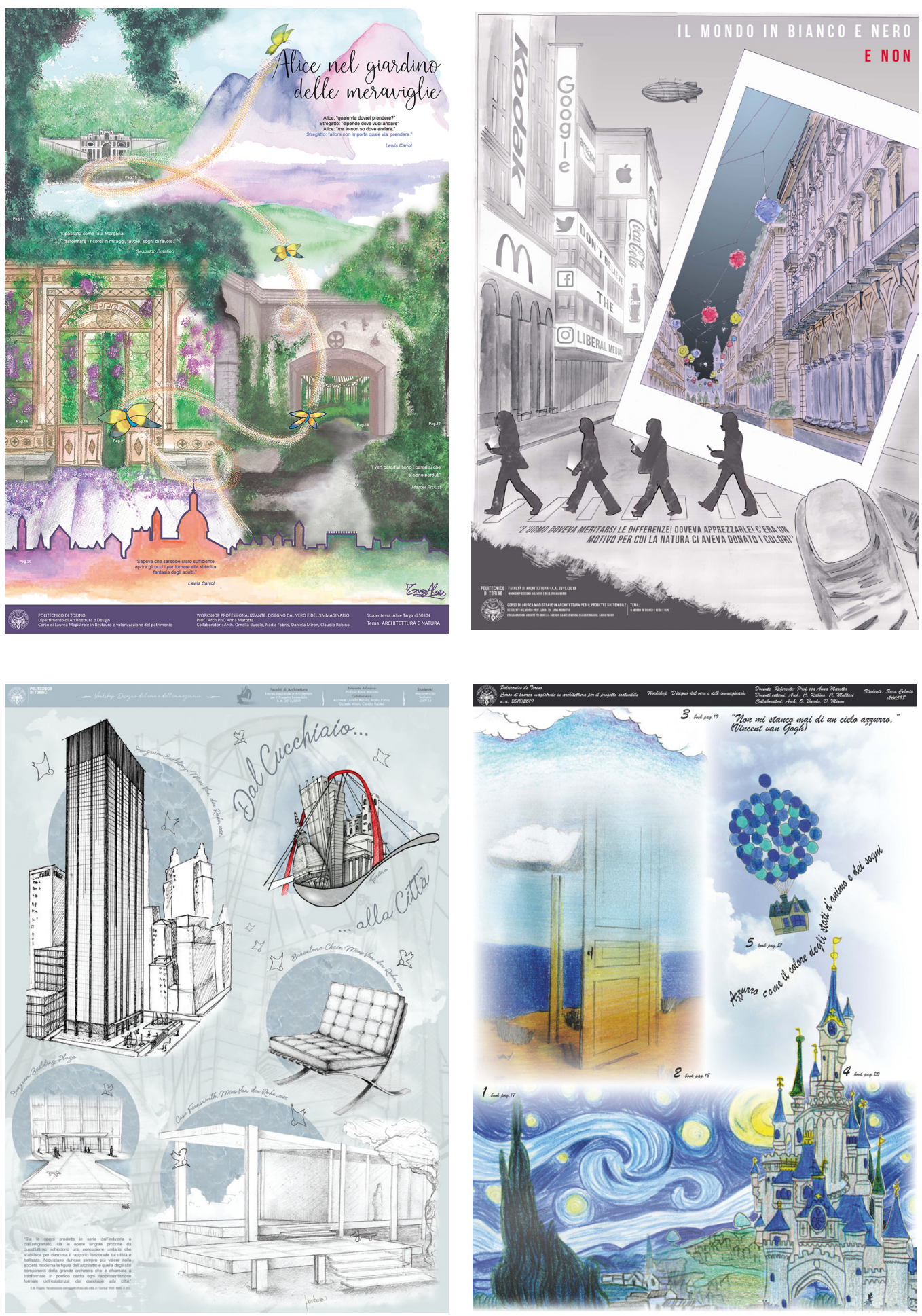


\title{
References
}

Albissini Piero, Chiavoni Emanuela, De Carlo Laura (a cura di). (20l0). Verso un disegno "integrato". La tradizione del disegno nell'immagine digitale. Roma: Gangemi Editore.

Arnheim Rudolph (1984). Arte e percezione visiva. Milano: Feltrinelli.

Bachelard Gaston (2006). La poetica dello spazio. (Traduzione di E. Catalano). Bari: Dedalo.

Bachelard Gaston (20 I0). L'intuizione dellistante-La psicoanalisi del fuoco. (Traduzione di M. Bianchi). Bari: Dedalo.

Castoldi Alberto, 20 I2. In carenza di senso. Logiche dell'immaginario. Milano: Mondadori.

Hachen Massimo (2007). Scienza della visione: spazio e Gestalt, design e comunicazione. Milano: Apogeo.

Kanizsa Gaetano (1980). Grammatica del vedere: saggi su percezione e Gestalt. Bologna: II mulino.

Kepes Gyorgy (1986). Il linguaggio della visione. Bari: Dedalo.

Marotta Anna (1999). Policroma: dalle teorie comparate al progetto del colore. Torino: Celid.

Marotta Anna (20I0). Segno e simbolo, rilievo e analisi. L'esempio nell'ornatus architettonico. In Centofanti Mario, Brusaporci Stefano. Sistemi informativi integrati per la tutela la conservazione e la valorizzazione del patrimonio architettonico e urbano. Roma: Gangemi Editore, p. I12-121.

Marotta Anna (20I I). Retorica della visione: dal paesaggio urbano ai sememi. In: Gambardella Carmine (a cura di). Le vie dei mercanti, S.A.V.E. Heritage safeguard of architectural, visual, environmental Heritage. Capri, 9- I I giugno 20 I I, p. I- I 0. Napoli: La scuola di Pitagora.

Netti Rossana (2019). II disegno dell'antico come metafora di conoscenza, comunicazione e conservazione della memoria. In: Belardi Paolo (a cura di). Riflessioni | Reflections | L'arte del disegno/ll disegno dell'arte. Atti del $41^{\circ}$ Convegno dei Docenti delle Discipline della Rappresentazione. Perugia 19-2I settembre 20 19. Roma: Gangemi Editore, 20 I9, pp. 847-854.

Piaget Jean, Inhelder Bärbel (1977). La genesi delle strutture logiche elementari. Classificazione e seriazione. Firenze: La Nuova Italia.

Pirenne Maurice (199|). Percezione visiva: ottica, pittura, fotografia. Padova: Muzio.

Rabino Claudio (2017).Trent'anni di arte e passione insieme. Torino: Politecnico di Torino, Regione Piemonte.

Sartre Jean-Paul (2007). L'immaginario. Psicologia fenomenologica dell'immaginazione (nuova edizione a cura di Raoul Kirchmayr). Torino: Einaudi.

Wunenburger Jean-Jacques (1997). Philosophie des images. Parigi: Presses Universitaires de France.

\author{
Authors \\ Anna Marotta, Politecnico di Torino, nannarella.marotta@gmail.com \\ Rossana Netti, Politecnico di Torino, rossana.netti@polito.it \\ Ornella Bucolo, Politecnico di Torino, ornella.bucolo@polito.it \\ Nadia Fabris, Politecnico di Torino, nadia.fabris@polito.it \\ Daniela Miron, Politecnico di Torino, daniela.miron@polito.it \\ Claudio Rabino, Politecnico di Torino, claudio.rabino@polito.it
}

To cite this chapter: Marotta Anna, Netti Rossana, Bucolo Ornella, Fabris Nadia, Miron Daniela, Rabino Claudio (2020). 'Disegno dal vero e dell'immaginario': le verità di un ossimoro visivo/'Drawing from life and imagination': the truths of a visual oxymoron. In Arena A., Arena M., Brandolino R.G., Colistra D., Ginex G., Mediati D., Nucifora S., Raffa P. (a cura di). Connettere. Un disegno per annodare e tessere. Atti del $42^{\circ}$ Convegno Internazionale dei Docenti delle Discipline della Rappresentazione/Connecting. Drawing for weaving relationships. Proceedings of the 42th Internationa Conference of Representation Disciplines Teachers. Milano: FrancoAngeli, pp. 608-625. 